\title{
Review of High Performance Aqueous Rechargeable Batteries Based on Layered Double Hydroxide
}

\author{
Hyeon Jeong Lee ${ }^{1}$, Ji Hoon Lee ${ }^{2, \dagger}$ \\ ${ }^{1}$ Department of Materials, University of Oxford, United Kingdom \\ ${ }^{2}$ School of Materials Science and Engineering, Kyungpook National University, Republic of Korea
}

\section{차세대 수계 이차전지용 층상 이중 수산화물 소재의 연구동향에 관한 리뷰}

\author{
이현정 ${ }^{1}$, 이지훈 ${ }^{2} \dagger$ \\ ${ }^{1}$ 옥스포드 대학교 재료과, ${ }^{2}$ 경북대학교 신소재공학부 \\ (Received February 19 2021; Revised March 1 2021; Accepted March 8 2021)
}

\begin{abstract}
s
Aqueous rechargeable batteries (ARBs) have drawn great attention as an alternative to the conventional non-aqueous lithium ion batteries (LIBS) because of the ever-growing demand for battery systems that are cheaper and safer than LIBs. However, it is challenging to find electrode materials for ARBs with promising and competitive properties in many aspects mainly due to the limited electrochemical window of water $(\approx 1.23$ $\mathrm{V}$ ) and the poor understanding of the operation mechanism. In this review, firstly introduced is the reason why the conventional LIB materials failed to exhibit satisfying performance in aqueous electrolytes, followed by a comprehensive understanding of layered double hydroxides as ARB cathode materials.
\end{abstract}

Keywords: Aqueous rechargeable batteries, Electrochemical analysis, Layered double hydroxides, Intercalant, Crystal water

1. 서론

에너지 저장 및 변환 기술은 범-지구적으로 증가하
고 있는 에너지 요구량에 맞물려 활발히 연구되고 있 다. 특히, 1991년 상용화 이후 현재에 리튬 이차전지 (Lithium ion batteries: LIBs)는 에너지 저장 매체로

${ }^{\dagger}$ Corresponding Author: Ji Hoon Lee

E-mail: jihoonlee@knu.ac.kr 
서 전지 시장을 이끌고 있으며 스마트 폰 · 노트북 용 소 형 전지, 전기 자동차 용 중형 전지 및 대용량 에너지 저 장 장치(Energy Storage Systems; ESSs)까지 활용되 고 있다. ${ }^{1-4)}$ 그러나, 제한적이고 편재화된 원자재의 매 장량과 그에 따른 높은 단가, 비-수계 전해질의 낮은 안 전성, 리튬의 폭발 가능성 등으로 인해 LIB의 한계점 또 한 꾸준히 지적되고 있는 상황이다. 안정성과 가격경쟁 력이 우수한 이차전지 시스템에 대한 수요가 증가함에 따라, 수계이차전지(Aqueous rechargeable batteries; $\mathrm{ARBs}$ )가 경쟁력있는 차세대 이차전지 중 하나로 평가 받고 있다. ${ }^{5)}$ 특히, 수분 제어시설이 필요없는 환경에서 물을 기반으로 하는 전해질을 이용해 셀을 제작할 수 있 기 때문에 기존의 엄격한 LIBs 설비 환경(수분 $20 \mathrm{ppm}$ 이하, 전해액 순도 > 99.9\%)에서 기인하는 생산 단가를 크게 낮출 수 있다는 장점은 주목할 만하다. 또한 대부 분의 수계 전해질은 비-수계 전해질에 비해 $10^{2} \sim 10^{3}$ 배 가량 높은 이온전도도를 갖고 있어 고속 충 - 방전이 가 능한 전기화학적 시스템을 제공한다. 이와 같은 장점에 도 불구하고, 수계 전해질의 좁은 전기화학적 구동 범위 (이론적: $\approx 1.23 \mathrm{~V}$, 실험적: $1.6 \sim 1.8 \mathrm{~V}$ )안에서 작동할 수 있는 소재를 찾아야 하기 때문에 $\mathrm{ARB}$ 용 양 - 음극 소 재를 발굴하는데 큰 어려움을 겪고 있다 (그림 1). ${ }^{6}$ 또 한, 수계 전해질에서 구동할 수 있는 전극 소재가 있다 고 하더라도, 소재와전해질 사이의 계면에서 발생하는

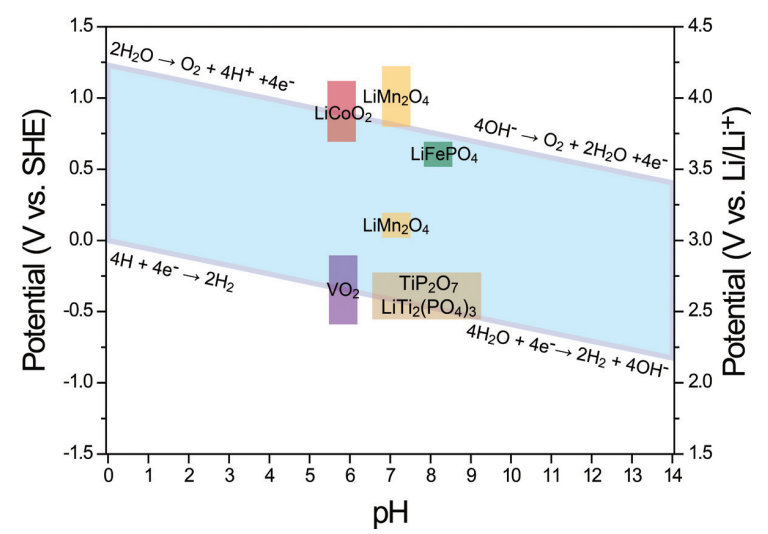

Fig. 1. Pourbaix diagram showing the electrochemical potential window of aqueous electrolytes with different $\mathrm{pH}$ values along with operating potentials of electrode materials.
연속적인 산화 - 환원 반응은 전지 성능의 심각한 열화 를 동반한다. 따라서, 기존 LIB에 사용된 전극 소재들이 수계 전해질에서 겪는 열화 반응을 종합적으로 이해하 고, 열화 반응을 억제할 수 있는 전략 탐색 및 안정한 계 면을 형성할 수 있는 소재를 연구하는 것은 $\mathrm{ARB}$ 성능을 향상시키는데 있어 필수적이라고 할 수 있다. 본 총설 논문에서는 기존의 비-수계 이차전지 소재들이 수계 전 해질에서 겪는 열화 메커니즘을 소개하고, 층상이중수 산화물(Layered double hydroxide; $\mathrm{LDH}$ )를 이용한 차 세대 $\mathrm{ARB}$ 시스템에 대한 연구 동향을 살펴보고자 한다.

\section{2. 수계 전해질에서 LIB소재의 열화 메커니즘 및 해결 방안}

\section{1. 음극 소재의 열화 반응: 용존 산소 제거의 중요성}

리튬 이온을 매개로 하는 수계 전지를 구축하는데 있 어 가장 먼저 시도한 접근법은 LIB 시스템에서 사용 중 인 소재를 활용하는 것이다. 1994년 Dahn et al. 은 리 튬 망가니즈 스피넬 $\left(\mathrm{LiMn}_{2} \mathrm{O}_{4} ; \mathrm{LMO}\right)$ 과 브론즈 상 바나 듐 산화물 $\left(\mathrm{VO}_{2}(\mathrm{~B})\right)$ 을 각각 양 - 음극으로 활용한 $1.5 \mathrm{~V}$ 급 $\mathrm{ARB}$ 시스템을 보고했다 $\left(\mathrm{VO}_{2}(\mathrm{~B})|5 \mathrm{M} \mathrm{LiNO} 3| \mathrm{LMO}\right.$, 식 (1) $-(2))^{1)}$

$$
\begin{gathered}
\mathrm{LiMn}_{2} \mathrm{O}_{4} \leftrightarrow \mathrm{x}\left(\mathrm{Li}^{+}+\mathrm{e}^{-}\right)+\mathrm{Li}_{1-\mathrm{x}} \mathrm{Mn}_{2} \mathrm{O}_{4} \\
\mathrm{x}\left(\mathrm{Li}^{+}+\mathrm{e}^{-}\right)+\mathrm{VO}_{2}(\mathrm{~B}) \leftrightarrow \mathrm{Li}_{\mathrm{x}} \mathrm{VO}_{2}(\mathrm{~B})
\end{gathered}
$$

그러나 $\mathrm{VO}_{2}(\mathrm{~B})$ 음극의 열화 및 $\mathrm{Mn}^{3+}$ 의 얀-텔 러 뒤틀림(Jahn-Teller distortion), 불균등화 반응 (Disproportionation reaction) 등으로 인한 $\mathrm{Mn}$ 이온 용출 등 $\mathrm{LMO}$ 양극의 열화로 인해 제한된 수명 특성 (100사이클 후 초기 용량의 50\% 유지)을 보였다.

Dahn et al. 연구에 영향을 받아, 다양한 양-음 극 소재들의 조합으로 $\mathrm{ARB}$ 시스템이 보고되었다. $\mathrm{LiV}_{3} \mathrm{O}_{8}\left|1 \mathrm{M} \mathrm{Li}_{2} \mathrm{SO}_{4}\right| \mathrm{LiNi}_{0.81} \mathrm{Co}_{0.19} \mathrm{O}_{2}$ (Köhler et al.), $\mathrm{LiTi}_{2}\left(\mathrm{PO}_{4}\right)_{3}\left|5 \mathrm{M} \mathrm{LiNO}{ }_{3}\right| \mathrm{LMO}$ (Chen et al.) 등이 대 표적인 예라 할 수 있다. ${ }^{7,8)}$ 특히, 바나듐 이온 $\left(\mathrm{V}^{4+}\right.$, $\mathrm{V}^{5+}$ ) 혹은 티타늄 이온 $\left(\mathrm{Ti}^{4+}\right)$ 기반의 브론즈 상 혹은 NASICON(Sodium super ion conductor) 상을 갖는 소재들은 다른 후 전이금속 이온들(예: $\mathrm{Ni}^{2+/ 3+}, \mathrm{Co}^{+3}$ )에 
비해 상대적으로 낮은 작동 전압을 갖고 있기 때문에음 극으로 활용한 점을 눈 여겨 볼만하다.

이들 음극 소재가 잘 발달된 작동 전압특성을 보임에 도 불구하고 그림 1 에서 확인할 수 있듯이, 리튬을 삽 입 · 탈리를 하는 “전지 반응”과 물을 분해시키는 “수소 발생 반응(Hydrogen evolution reaction)”은 서로 경 쟁관계에 있게 된다. 이 과정에서 대부분의 음극 소재 는 심각한 열화를 겪게 되는데, 이 과정을 Xie et al.에 서 열역학적으로 증명하였다. ${ }^{6)}$ 이 열화 과정은 리튬이 온이 삽입된 음극 소재(Lithiated anode)가 수계 전 해질의 용존 산소에 의해 화학적으로 산화되기 때문이 며, 간단한 (1) $\mathrm{Ar}$ 전해질 퍼징(=용존 산소 제거)과 (2) 전해질의 $\mathrm{pH}$ 조절을 통해 해소할 수 있었다. 이를 통 해 최적화된 $\mathrm{LiTi}_{2}\left(\mathrm{PO}_{4}\right)_{3} \mid 1 \mathrm{M} \mathrm{Li}_{2} \mathrm{SO}_{4}(\mathrm{pH}=13$ with $\mathrm{LiOH}) \mid \mathrm{LiFePO}_{4}(\mathrm{LFP}) \mathrm{ARB}$ 셀은 1,000 회 충 · 방전 후 에도 열화가 없는 성능을 보였다.

\subsection{LIB 양극 소재의 열화 반응: 용존 산소 제거, 구동 온도 및 $\mathrm{pH}$ 최적화}

후 전이금속이온 $\left(\mathrm{Mn}^{3+/ 4+}, \mathrm{Co}^{3+/ 4+}, \mathrm{Ni}^{2+/ 3+/ 4+}\right)$ 의 레독 스 반응을 이용하는 LIB 양극 소재의 경우, 대체로 리 튬 금속 대비 $\sim 4 \mathrm{~V}\left(\right.$ VS. Li $\left./ \mathrm{Li}^{+}\right)$의 전압을 갖고 있으므 로 $\mathrm{pH}=7$ 의 중성 수계 전해질(예: $1 \mathrm{M} \mathrm{LiNO}_{3}$ )에서 표준 수소 전극 대비 $0.96 \mathrm{~V}$ (vs. SHE)의 전압을 갖게 된다 (그림 1). 따라서, 상대적으로 안정적인 전기화학 반응 을 할 것으로 예상했으나, 소재의 구조에 따라 서로 다 른 열화 메커니즘이 보고되었다. ${ }^{9-12)}$ 층상 구조(Layered structure)를 갖는 소재 $\left(\mathrm{LiTMO}_{2}, \mathrm{TM}=\mathrm{Ni}, \mathrm{Co}, \mathrm{Mn}\right.$, $\mathrm{Al}$, etc., 예: $\left.\mathrm{LiCoO}_{2} ; \mathrm{LCO}\right)$ 는 수계 전해질에 있는 프 로톤 $\left(\mathrm{H}^{+}\right)$이 리튬이온과 함께 삽입 $(\mathrm{Co}-$ intercalation $)$ 되고 그 결과 입자 표면이 $\mathrm{Li}_{x} \mathrm{Co}_{2} \mathrm{O}_{4}$ 의 스피넬 상으로 열 화된다. ${ }^{13)}$ 상기 언급한 스피넬 구조를 갖는 $\mathrm{LMO}$ 의 경 우 얀-텔러 뒤틀림 및 불균등화 반응으로 인한 $\mathrm{Mn}$ 이온 손실 및 격자 변형으로 열화가 일어난다. 올리빈 구조를 갖는 $\mathrm{LFP}$ 의 경우 염기 분위기에서 분해가 되지만, 표면 에 보호층(예: 카본)을 코팅함으로써 열화를 방지할 수 있다. ${ }^{14)}$
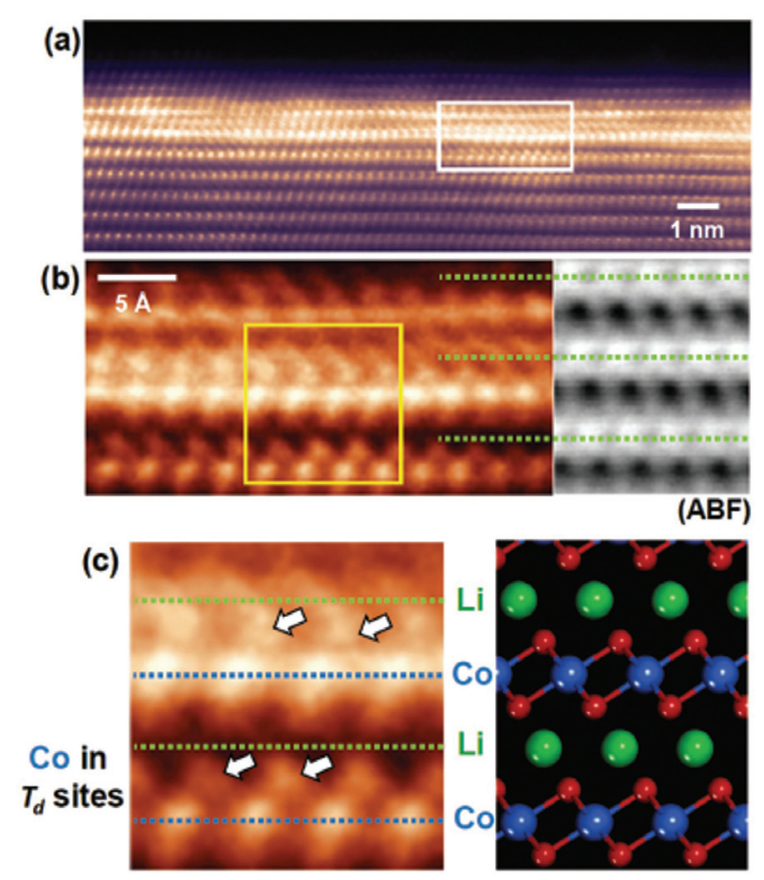

Fig. 2. Atomic-scale STEM images of LCO showing the migration of $\mathrm{Co}$ atoms into tetrahedral site in the progress of $\mathrm{Li}$ and $\mathrm{Co}$ atom dissolution. Adapted from Chung et al. Adv Funct Mater 2018;28:1804564, with permission of Wiley Press [15].

최근 Chung et al. 에서 LFP와 LCO 단결정(Single crystal)을 활용하여 온도와 용존 산소가 열화 과정 에 미치는 영향을 체계적으로 분석했다. ${ }^{15)}$ 용존 산소 가 LFP 표면의 열화에 미치는 영향은 거의 없었으나, 전해질의 온도를 상온에서 $40^{\circ} \mathrm{C}$ 로 올릴 경우 급격하 게 인(P)이 용출되며 표면에 $\mathrm{Fe}_{3} \mathrm{O}_{4}$ 가 형성되는 방식으 로 열화가 진행됨을 투과전자현미경으로 확인했다. 이 에 비해, $\mathrm{LCO}$ 의 경우 온도보다는 용존 산소가 더욱 크 게 영향을 미치는 것으로 나타났다. 투과전자현미경 분 석과 함께 $\mathrm{Ab}$ initio 계산을 통해 확인한 결과, $\mathrm{Li}$ 이온 및 $\mathrm{Co}$ 이온이 용출되는 과정에서 $\mathrm{Co}$ 이온이 사면체 자리 (Tetrahedral site)로 이동하는 특이한 현상을 보고했다 (그림 2). 전해질의 온도와 용존 산소 조절이 $\mathrm{ARB}$ 구동 에 미치는 영향을 원자 수준에서의 이해를 제공했다는 점에서 이와 같은 연구는 의미있다고 할 수 있다.

Choi et al. 에서 한 번의 열처리 공정으로 $\mathrm{LCO}$ 표면을 스피넬 상 $\mathrm{Co}_{3} \mathrm{O}_{4}$ 로 개질할 수 있는 방법론을 제시했다 
(A)

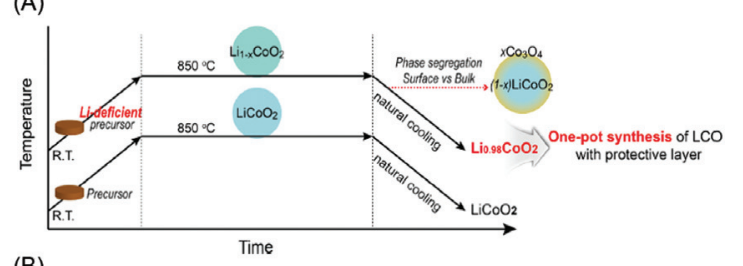

(B)

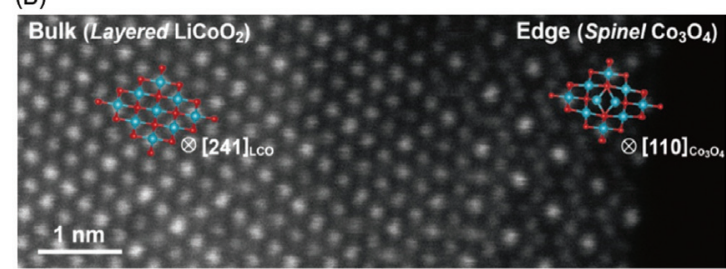

(C)
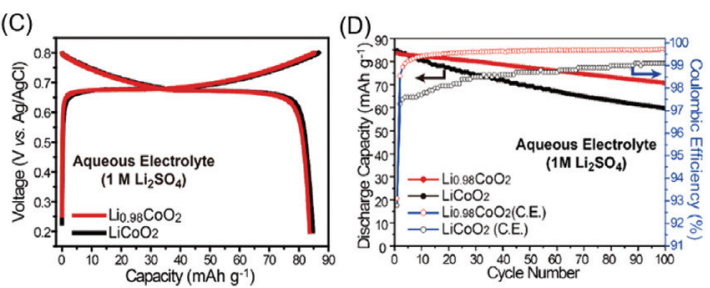

Fig. 3. (A) Schematic synthetic routes for $\mathrm{LiCoO}_{2}$ surrounded by spinel- $\mathrm{CO}_{3} \mathrm{O}_{4}\left(\mathrm{Li}_{0.98} \mathrm{CoO}_{2}\right)$ and bare $\mathrm{LiCoO}_{2}$. (B) Atomic-resolution STEM image for $\mathrm{Li}_{0.98} \mathrm{CoO}_{2}$. (CD) Comparative galvanostatic profiles of $\mathrm{Li}_{0.98} \mathrm{CoO}_{2}$ and $\mathrm{LiCoO}_{2}$ in (C) aqueous and (D) non-aqueous electrolytes. Reproduced from Choi et al. ACS Appl Energy Mater 2018;1:5726-34, with permission of American Chemical Society Press[17]

(그림 3). ${ }^{16)}$ 리튬이 $2 a t \%$ 정도 모자란 환경에서 적절한 조건의 열처리를 하면, 열역학적으로 저온에서 안정한 $\mathrm{CO}_{3} \mathrm{O}_{4}$ 가 식힘 과정 동안 $\mathrm{LCO}$ 표면에 매우 균일하게 형 성되는 것을 확인할 수 있었고, 이 개질층이 $\mathrm{LCO}$ 가 수 계 전해질과의 직접적인 접촉을 억제함으로써 향상된 $\mathrm{ARB}$ 성능을 확인할 수 있었다. 특히, 향상된 쿨롱 효율 은 스피넬 층이 프로톤의 동시 삽입 반응을 효과적으로 억제함으로써 리튬 이온의 탈리 · 삽입을 더욱 원활하게 해준다는 것을 의미하기 때문에 더욱 주목할 만한 부분 이다. 이와 같은 결과는 $\mathrm{LCO}$ 소재 또한 표면에 효과적 인 코팅층(다른 전이금속 산화물, 카본, 폴리머 등)을 도 입하면 향상된 $\mathrm{ARB}$ 성능을 기대할 수 있다는 점을 시사 한다는 점에서 의미가 있다.

\section{3. 층상 이중 수산화물을 활용한 $\mathrm{ARBs}$}

상기 2절에서 확인할 수 있듯이, 많은 연구에도 불 구하고 $\mathrm{LIB}$ 소재를 $\mathrm{ARB}$ 전극으로 활용하는 것은 전해 질과의 불안정한 계면 형성으로 인해 쉽지 않음을 확 인할 수 있었다. 그러므로, 전해질과 안정한 계면을 형 성할 수 있는 $\mathrm{ARB}$ 전극 소재를 탐색하는 것은 합리적 인 전략이라고 할 수 있다. 바닷가나 냇가에서 발견되 는 소재들이 대부분 수화물(Hydrated compounds)라 는 것을 생각해보면 전이 금속을 기반으로 하는 수화물 은 전해질과 안정한 계면을 형성할 수 있기 때문에 좋 은 $\mathrm{ARB}$ 소재 후보군이라고 할 수 있다. ${ }^{17)}$ 본 3 절에서는 수화물 중 하나인 층상 이중 수산화물(Layered double hydroxide; $\mathrm{LDH})$ 를 활용한 $\mathrm{ARB}$ 연구들을 리뷰하고자 한다.

\section{1. 수산회물 구조에 대한 총설}

일반적인 전이금속 산화물 $\left(\mathrm{TM}_{\mathrm{x}} \mathrm{O}_{\mathrm{y}}, \mathrm{TM}=\mathrm{Ni}, \mathrm{Co}, \mathrm{Mn}\right.$, $\mathrm{Fe}$, etc.)과는 다르게, 수산화물(Hydroxide)는 전이금 속이 수산기 $\left(\mathrm{OH}^{-}\right)$에 의해 배위된 구조체를 지칭한다. ${ }^{18)}$ 일반적으로 수산화물은 수산기가 풍부한 수용액에서 침 전(Precipitation)을 통해서 얻을 수 있으며, 합성 조건 에 따라 단결정 - 다결정 구조 등 다양하게 얻을 수 있 다. 수산화물을 산화 분위기에서 어닐링하면 수산기가 열분해되어 산화물을 얻을 수 있기 때문에, 종종 다양한 산화물 소재의 전구체(Precursor)로 활용된다. ${ }^{19)}$

수산화물(Hydroxide)는 크게 알파상( $\alpha$-phase) 과 베 타상 $\left(\beta\right.$-phase)으로 나눌 수 있다 (그림 4). ${ }^{18-22)}$ 일반적 으로, 잘 알려진 $\beta$-phase 수산화물은 브루사이트 광물 구조(Brucite, $\left.\mathrm{Mg}(\mathrm{OH})_{2}\right)$ 를 기반으로 하고 있다. 전이금 속이 여섯 개의 수산기로 둘러쌓인 팔면체(Octahedron) 가 선공유(Edge-sharing)을 통해 2차원 층을 형성하 고, 이 전이금속 층(Slab)들은 $\mathrm{ABAB}$ 방식으로 적층되 어 Trigonal 결정 구조 $\left(\mathrm{P}-3 \mathrm{~m}, \mathrm{a}_{0}=\mathrm{b}_{0} \approx 3.1 \AA, \mathrm{c}_{0} \approx 4.7\right.$ $\AA, \gamma=120^{\circ}$ )를 형성한다. 전이금속 층 사이에는 층과 층 을 이어주는 약한 힘이 존재하는데, 이 힘의 본질(분산 력 vS. 수소결합)에 대해서는 여전히 많은 논란이 있 
(A)

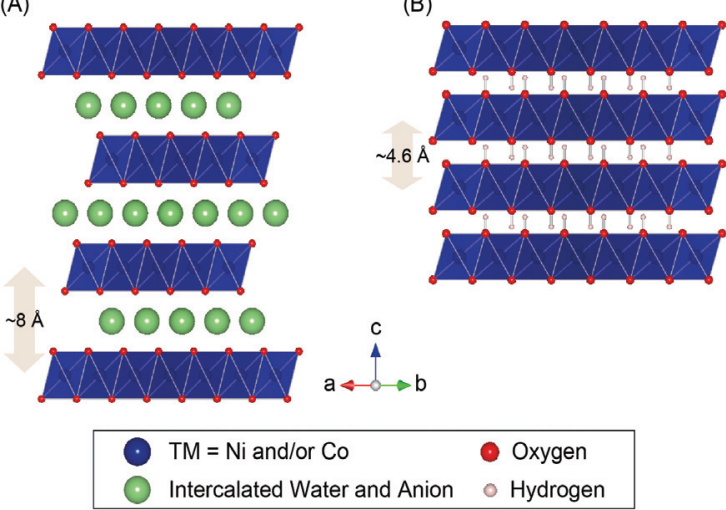

Fig. 4. Crystal structure of (A) $\alpha$-phase and (B) $\beta$-phase hydroxides viewed along the [110] direction. Adapted from Choi et al. Adv Funct Mater 2017;27:1605225, with permission of Wiley Press[37]

다. ${ }^{23,24)}$ 수산기의 특징을 고려할 때 수소 결합으로 이해 하는 것이 합리적이라 생각할 수 있으나 수산기의 기하 학적인 결합구조(Geometric configuration)를 고려해 보면, $\mathrm{A}$ 층의 산소와 $\mathrm{B}$ 층의 수소 사이의 거리가 수소 결 합이 일어나는 일반적인 결합 길이에 비해 다소 길다는 점을 알 수 있다. 그러나, 점진적 가압 조건에서 수행 한 분광 분석에 의하면 $\mathrm{O}-\mathrm{H}$ stretching의 frequency 가 가압 조건에서 점차 감소했는데, 이는 전형적인 수소 결합에서 일어나는 특징이다. ${ }^{25)}$ 이와 같은 결과들을 바 탕으로 생각할 때 $\beta$-phase 수산화물의 층간 사이의 결 합력은 많은 논란이 있지만, 실험 환경에 따라 분산력과 수소결합이 함께 작용할 수 있다고 결론 내릴 수 있다.

$\beta$-phase 수산화물의 약한 층간 결합으로 인해, 합 성 과정에서 다양한 층간 삽입물(Intercalant)들이 들어 갈 수 있다. 이때, 음이온 $\left(\mathrm{Cl}^{-}, \mathrm{NO}_{3}{ }^{-}, \mathrm{CH}_{3} \mathrm{COO}^{-}, \mathrm{SO}_{4}{ }^{2-}\right.$ 등)과 함께 결정수(Crystal water)가 전이금속 층 사이 에 존재한 채 결정화가 되면 $\alpha$-phase 수산화물을 얻 을 수 있게 된다. $\alpha$-phase 수산화물은 삽입된 음이온 과 결정수로 인해, $\beta$-phase 수산화물에 비해 층간 거 리가 늘어나고 $\mathrm{ABCABC}$ 순서로 적층 방식이 바뀌게 되며 Rhombohedral 구조 $\left(\mathrm{R}-3 \mathrm{~m}, \mathrm{a}_{0}=\mathrm{b}_{0} \approx 3.1 \AA, \mathrm{c}_{\mathrm{o}}\right.$ $\approx 24 \AA, \gamma=120^{\circ}$ )를 갖는다. $\alpha$-phase 수산화물 구조 를 갖는 대표적인 광물인 Hydrotalcite $\left(\left(\mathrm{Mg}_{0.75} \mathrm{Al}_{0.25}\right)\right.$
$\left.(\mathrm{OH})_{2}\left[\left(\mathrm{CO}_{3}\right)_{0.125} \mathrm{O} .5\left(\mathrm{H}_{2} \mathrm{O}\right)\right]\right)$ 에서 이름을 차용해 해당 구 조를 명명하고 있고 흔히 $\mathrm{LDH}$ 라고 부른다. 화학식에서 알 수 있듯이, 음이온이 들어간 양만큼의 전이금속이 3 가(Trivalent)로 산화되어 전체적인 전하 보상이 일어나 는 것을 알 수 있다. 음이온을 상대적으로 쉽게 치환할 수 있기 때문에 면간 거리(Interlayer spacing, i.e., co) 를 다양하게 조절할 수 있고 그에 따라 물리화학적 특성 도 조절 가능하다. 일반적으로 질산염 $\left(\mathrm{NO}_{3}{ }^{-}\right)$혹은 염화 이온 $\left(\mathrm{Cl}^{-}\right)$을 기반으로 하는 $\mathrm{LDH}$ 가 가장 보편적으로 합 성 · 보고되고 있다. ${ }^{19)}$

\section{2. 수산화물을 활용한 수계이차전지 구성 및 평가: 집전체 선택의 중요성}

상기 3.1절에서 언급한 바와 같이 $\mathrm{LDH}$ 는 $\beta$-phase 수산화물와 달리 결정수를 갖고 있기 때문에 충·방전 과정에서 캐리어 이온과 호스트 구조(Host framework) 간의 반발력을 최소화시킬 수 있다는 장점이 있다. 또 한, 반복된 사이클에서 생기는 구조 변형을 결정수가 효 과적으로 완화시켜줄 수 있기 때문에 다양한 전이금속 (Ni, Co, Al, Ti 등)을 기반으로 하는 단일 TM기반 혹은 다성분계 $\mathrm{TM}$ 기반 $\mathrm{LDH}$ 를 전극으로 하는 고성능 $\mathrm{ARB}$ 가 보고되었다. ${ }^{21,26-35)} \mathrm{LDH}$ 가 염기성 수용액 전해질에 서 전지 반응을 하기 때문에, 대부분의 연구는 염기성 전해질에서 수행되었다. 그러나, 비슷한 조성 - 합성방 법 · 측정 조건에도 불구하고 $\mathrm{LDH}$ 들은 서로 상이한 용 량(Capacity, $\mathrm{mAh} / \mathrm{g}$ )을 보였다. 이와 같은 이유에 대 해서, Xing et al. 은 집전체의 기생 용량을 지목했다. ${ }^{36}$ 높은 용량을 보고한 논문의 경우 니켈 폼(Ni foam) 혹 은 니켈 포일(Ni foil)을 집전체로 활용했는데, 이 경우 니켈 집전체 표면이 전기화학적으로 용량에 기여할 수 있는(Electroactive) 니켈 산화물 $(\mathrm{NiO})$ 혹은 니켈 수산 화물 $\left(\beta-\mathrm{Ni}(\mathrm{OH})_{2}\right)$ 로 상전이하여 전극 소재의 용량을 과 장(Exaggeration)시킬 수 있다는 점을 X선 광전자 분광 기(XPS)와 순환전류주사법(Cyclic voltammetry) 등을 통해 밝혔다. 특히, 해당 연구에서는 염기성 수용액 전 해질에서 용량에 기여하지 않는 집전체(예: 티타늄 포일 

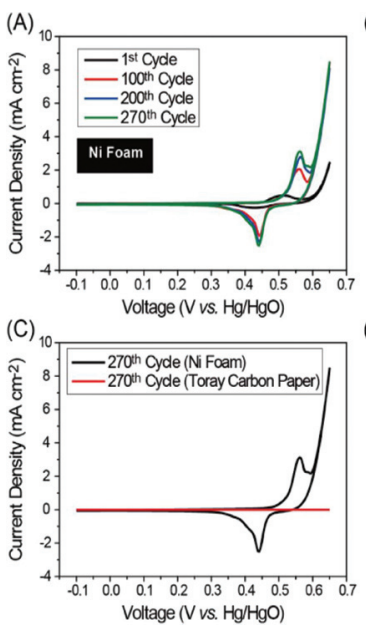

Fig. 5. Cyclic voltammetry curves of $\mathrm{Ni}$ foam and carbon paper $(1 \mathrm{M} \mathrm{NaOH}$, Scan rate $=5 \mathrm{mV} / \mathrm{sec})$. Adapted from Choi et al. Adv Funct Mater 2017;27:1605225, with permission of Wiley Press [37]

혹은 플래티넘 포일)를 사용해야 신뢰성있는 연구 결과 를 얻을 수 있다는 점을 지목했다는 점에서 시사하는 바 가 크다고 할 수 있다.

Choi et al. 은 카본 페이퍼를 염기성 전해질에서 기 생 용량 없는 집전체로 제시했다 (그림 5). ${ }^{37)}$ 해당 카본 페이퍼는 표면 산화 · 환원 반응이 없을 뿐만 아니라 약 $5 w t \%$ 가량 Polytetrafluoroethylene (PTFE) 표면 방수 처리로 인해 물과의 친화도가 매우 낮아 $1 \mathrm{M} \mathrm{NaOH}$ 에서 $0.6 \mathrm{~V}$ vs. $\mathrm{Hg} / \mathrm{HgO}$ (=1.7 V vs. reversible hydrogen electrode)까지 무시할만한 물 분해 전류를 보였기 때 문에 전극의 전기화학 반응을 관찰하기에 적합한 것으 로 보고했다. 또한 가격적인 측면에서도 카본 페이퍼가 Xing et al. 에서 제안한 금속 포일보다 훨씬 우수하기 때문에 염기성 수용액에서 $\mathrm{LDH}$ 를 평가하기에 가장 적 합하다고 할 수 있다. 다만, 고전류 측정 시, 카본 전극 의 다소 높은 면저항 특성 $(400 \mathrm{~mm} * 400 \mathrm{~mm} * 0.2 \mathrm{~mm}$, $80 \mathrm{~m} \Omega / \mathrm{cm}$ (두께 방향), $5.8 \mathrm{~m} \Omega / \mathrm{cm}$ (평면 방향))으 로 인해 소재의 고속 충 - 방전 특성을 관찰하기 어렵다 는 단점이 있다. 해당 특성이 중요한 측정의 경우 티타 늄 포일 등을 활용할 수 있다.

\section{3. 전이금속 선택의 중요성}

$\mathrm{LDH}$ 를 기반으로 하는 $\mathrm{ARB}$ 전극 소재는 대부분 $\mathrm{Ni}$ 을 공통적으로 포함하고 있다. 그 이유는 $\mathrm{Ni}$ 은 $\mathrm{Ni}^{2+}$ 에서 $\mathrm{Ni}^{4+}$ 까지 넓은 레독스(Redox) 범위로 인해 다른 전이금 속에 비해 높은 가용 용량을 확보할 수 있기 때문이다. 그러나, $\mathrm{Ni}$ 로만 이뤄진 $\mathrm{LDH}$ (이하, $\mathrm{Ni}-\mathrm{LDH}$ )는 높은 초 기 용량에도 불구하고 충 - 방전 중에 거치게 되는 중간 상태인 $\mathrm{Ni}^{3+}$ 로 인해 심각한 얀-텔러 뒤틀림을 겪게 되 고, 이로 인해 $\mathrm{Ni}$ 전이금속 층이 심각한 격자 변형을 겪 게 된다. ${ }^{38)} \mathrm{LDH}$ 의 층간 삽입물은 격자 변형 과정에서 점차 용출되고, 그 결과 높은 용량을 낼 수 있는 $\mathrm{LDH}$ 상 (그림 $4 \mathrm{~A}$ )이 $\beta-\mathrm{Ni}(\mathrm{OH})_{2}$ (그림 $4 \mathrm{~B}$ )로 상전이를 거쳐 열 화된다.

이와 같이 $\mathrm{Ni}-\mathrm{LDH}$ 의 열화를 억제하고자, 알루미늄 $\left(\mathrm{Al}^{3+}\right)$ 이나 코발트 $\left(\mathrm{Co}^{3+}\right)$ 같이 금속-산소 팔면체를 안정 화시킬 수 있는 금속이온들을 $\mathrm{Ni}$ 자리에 도핑 - 치환하는 전략이 활발히 이용됐다. ${ }^{28,32)}$ Chen et al. 은 Ni-LDH 가 염기성 용액(6M KOH)에 담지(Aging)시켜놓아도 $\beta$ $-\mathrm{Ni}(\mathrm{OH})_{2}$ 로 열화가 발생하는 것을 확인했다. ${ }^{32)}$ 그러나, $\mathrm{Ni}$ 을 $\mathrm{Al}$ 으로 치환을 하면 위와 같은 열화가 현저히 억 제되는 것을 확인했고, $20.4 \mathrm{at} \%$ 의 $\mathrm{Al}$ 치환이 가장 최 적화된 조성 $\left(\mathrm{Ni}_{0.8} \mathrm{Al}_{0.2}-\mathrm{LDH}\right)$ 으로 제시했다. $\mathrm{Ni}_{0.8} \mathrm{Al}_{0.2}-$ $\mathrm{LDH}$ 는 $1 \mathrm{C}$ 와 $2 \mathrm{C}$ 조건에서 각각 $391 \mathrm{mAh} / \mathrm{g}$ 과 354 $\mathrm{mAh} / \mathrm{g}$ 의 용량을 보였고 약 100 회 충 · 방전 이후에도 용량 손실이 없음을 확인할 수 있었다. 특히, $\mathrm{Al}^{3+}$ 를 도 입하면 충 - 방전 곡선이 $\mathrm{Ni}-\mathrm{LDH}$ 보다 조금 더 위로 이 동한다(Upshift)는 점을 주목할 만하다. 이는 $\mathrm{Al}^{3+}$ 의 치 환으로 인해 $\mathrm{Ni}^{2+}$ 와 $\mathrm{Al}^{3+}$ 가 함께 공유(share)하는 산소 는 $\mathrm{Ni}^{2+}$ 의 전자 구름을 더욱 강하게 당기게 되고, 그 결 과 $\mathrm{Ni}^{2+/ 3+}$ 및 $\mathrm{Ni}^{3+/ 4+}$ 의 산화 반응이 일어나기 어려워지 기 때문에 해당 레독스 커플(Redox couple)이 Upshift 한 것이다. 이는 일반적인 완전 전지(Full Cell)에서 에 너지 밀도 $(\mathrm{Wh} / \mathrm{kg})$ 를 높일 수 있는 유용한 전략이 될 수 있다. 그러나, $0.4 \mathrm{~V} \mathrm{vs.} \mathrm{Hg} / \mathrm{HgO}$ 의 전압은 물이 분해 되어 산소가 발생되는 전압보다 $0.136 \mathrm{~V}$ 가량 높기 때 문에 안정적인 $\mathrm{ARB}$ 구동을 할 수 있는 양극 소재 합성 전략이라고 보기는 어려울 것이다.

이와 같은 관점에서 $\mathrm{Ni}$ 자리에 $\mathrm{Co}$ 를 치환하는 전략 

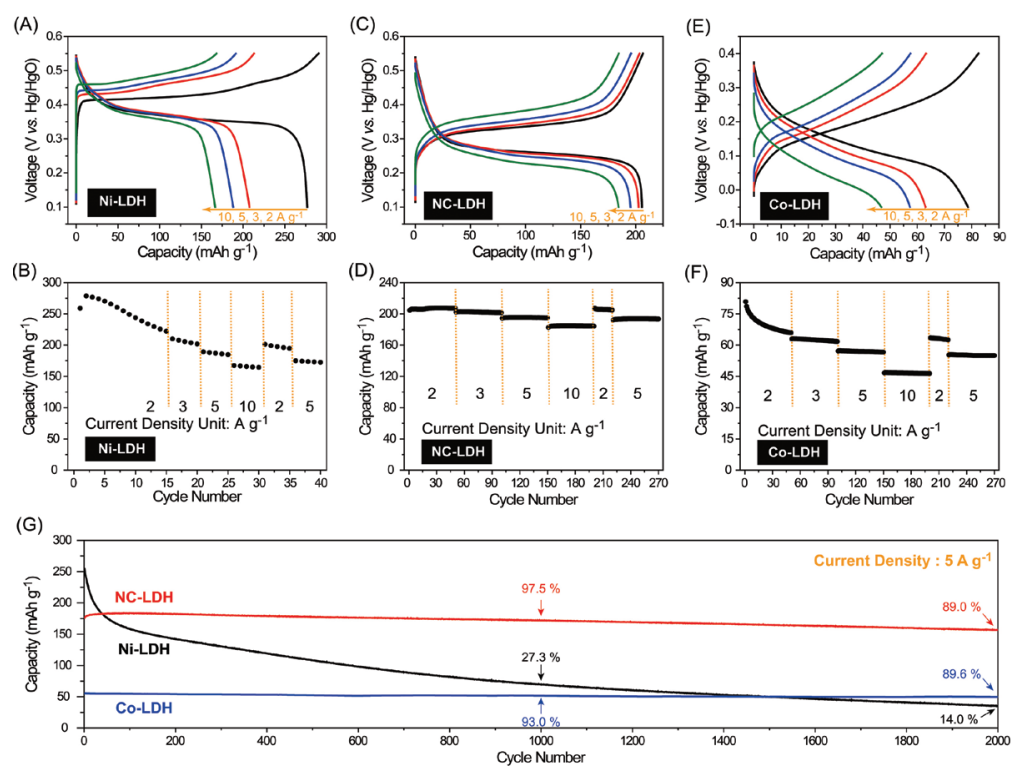

Fig. 6. The galvanostatic charge-discharge profiles and rate capabilities of (A, B) Ni-LDH, (C, D) NC-LDH, and (E, F) Co$\mathrm{LDH} . \mathrm{G})$ The cycling performance of the three compounds at $5 \mathrm{~A} \mathrm{~g}^{-1}$. Reproduced from Choi et al. Adv Funct Mater 2017;27:1605225, with permission of Wiley Press [37]

은 Ni의 작동전압을 아래로 이동(downshift)시킬 수 있 을 뿐만 아니라, 매우 안정적으로 $\mathrm{Ni}^{2+/ 3+/ 4+}$ 레독스 커 플을 활용할 수 있기 때문에 유용하다고 할 수 있다. 대 표적인 사례로 Choi et al. 은 $\mathrm{Ni}$ 의 절반을 $\mathrm{Co}$ 로 치환한 $\mathrm{Ni}_{0.5} \mathrm{Co}_{0.5}-\mathrm{LDH}(\mathrm{NC}-\mathrm{LDH})$ 를 보고했고 $\mathrm{NC}-\mathrm{LDH}$ 의 전기화학적 특성을 $\mathrm{Ni}-\mathrm{LDH}$ 와 $\mathrm{Co}-\mathrm{LDH}$ 와 함께 비교 했다. ${ }^{37)} \mathrm{Ni}-\mathrm{LDH}$ 는 앞서 언급한 경우와 마찬가지로 초 기의 높은 방전용량 $(\sim 276 \mathrm{mAh} / \mathrm{g})$ 에도 불구하고 100 사이클 이후 $\beta-\mathrm{Ni}(\mathrm{OH})_{2}$ 으로 구조 열화가 발생했다. 이 에 반해, $\mathrm{Co}-\mathrm{LDH}$ 의 경우 $\beta-\mathrm{Co}(\mathrm{OH})_{2}$ 으로 열화하기 보다는 비정질화되는 것을 확인하였다. $\mathrm{Ni}-\mathrm{LDH}$ 와 다 른 $\mathrm{Co}-\mathrm{LDH}$ 의 구조 열화 메커니즘은 $\mathrm{Co}$ 와 $\mathrm{O}$ 의 에너지 상태 밀도 준위(Density of States)로 이해할 수 있다. $\mathrm{Co}^{2+/ 3+}$ 레독스 커플은 $e_{\mathrm{g}}$ 레벨에서 작동하지만, $\mathrm{Co}^{3+/ 4+}$ 레독스 커플은 $t_{2 \mathrm{~g}}$ 레벨에서 작동하기 때문에 격자 산소 의 $2 \mathrm{p}$ 오비탈과 겹치게 된다. 이때 열역학적으로 격자 산소가 산화하는 것이 더욱 선호되어 격자 산소 용출이 일어나게 되고 $\left(\mathrm{O}^{2-} \rightarrow 0.5 \mathrm{O}^{0} \uparrow\right) \mathrm{Co}-\mathrm{LDH}$ 는 비정질화 가 일어나게 된다. $\mathrm{Ni}$ 과 $\mathrm{Co}$ 가 반씩 존재하는 $\mathrm{NC}-\mathrm{LDH}$ 의 경우, $\mathrm{Co}$ 는 $\mathrm{Co}^{3+}$ 로 고정되어 전기화학적으로 전이금
속 층의 구조적 안정화를 가해주는 한편 $\mathrm{Ni}$ 이 $2+$ 에서 $4+$ 까지 산화수 변화를 하는 동안 생기는 격자 변형을 완화해주기 때문에 고용량 $(206 \mathrm{mAh} / \mathrm{g}$ at $2 \mathrm{~A} / \mathrm{g})$, 고출 력(1분 충 · 방전 시, $185 \mathrm{mAh} / \mathrm{g})$, 장수명 특성(2000회 충 - 방전 후, 초기용량 $89 \%$ 유지)을 동시에 가질 수 있 음을 확인할 수 있었다 (그림 6).

$\mathrm{NC}-\mathrm{LDH}$ 의 경우, $\mathrm{Ni}$ 을 $50 \%$ 가량 $\mathrm{Co}$ 로 치환함으로 써 작동전압을 $\mathrm{Ni}-\mathrm{LDH}$ 에 비해 $0.1 \mathrm{~V}$ 가량 아래로 내 릴 수 있었다 $(0.412 \rightarrow 0.312 \mathrm{~V} \mathrm{vs.} \mathrm{Hg} / \mathrm{HgO})$. 이는 $1 \mathrm{M}$ $\mathrm{NaOH}$ 에서 물이 분해되어 산소가 발생되는 전압(0.264 $\mathrm{V} \mathrm{vs.} \mathrm{Hg} / \mathrm{HgO}$ )에 비해 약 $0.05 \mathrm{~V}$ 높은 수치로서 수계 이차전지 구성 시, 에너지 밀도를 최적화할 수 있는 작 동 전압인 것을 확인할 수 있다.

$\mathrm{Ni}$ 을 기반으로 하는 $\mathrm{LDH}$ 는 높은 용량에도 불구하고 얀-텔러 뒤틀림으로 인한 구조적 안정성이 확보되지 않 은 소재이다. 전이금속 층을 안정화시킬 수 있는 금속 이온을 치환 - 도핑하는 전략은 매우 유용하나, $\mathrm{Ni}$ 의 레 독스 커플은 도입된 전이금속에 의해 쉽게 에너지 준위 가 바뀔 수 있다. 따라서, 치환하고자 하는 전이금속이 전이금속 층을 안정화시키는 영향뿐만 아니라, $\mathrm{Ni}$ 의 레 


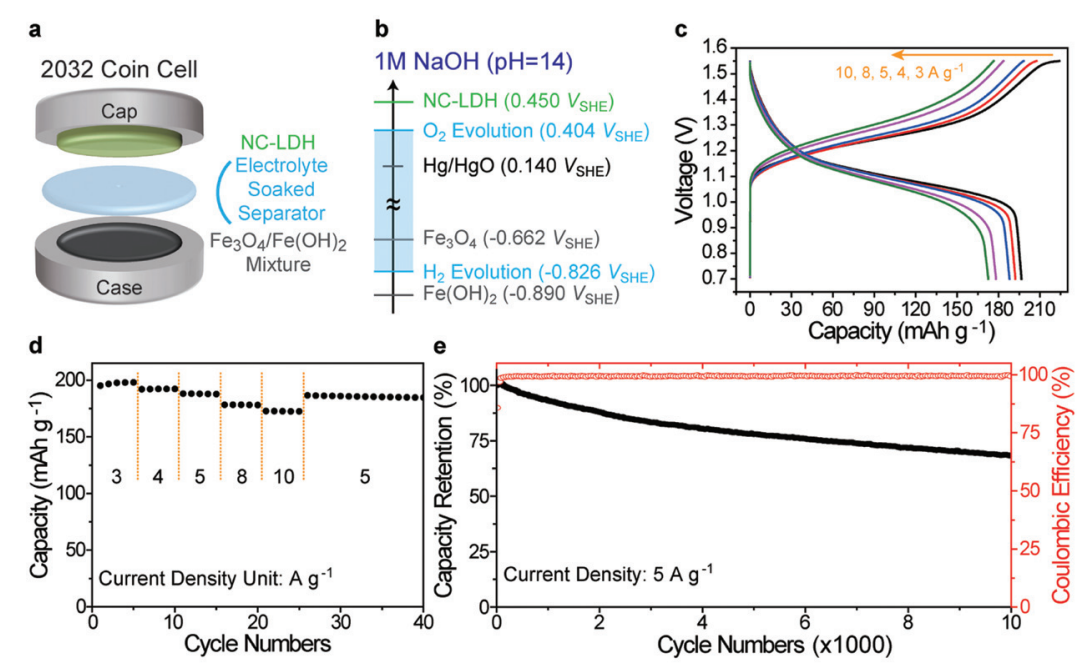

Fig. 7. $\mathrm{ABR}$ cell consisting of $\mathrm{NC}-\mathrm{LDH}|1 \mathrm{M} \mathrm{NaOH}| \mathrm{Fe}_{3} \mathrm{O}_{4}$ and its electrochemical performance. Adapted from Choi et al. Adv Energy Mater 2018;18:1703572, with permission of Wiley Press [39]

독스 커플에 미치는 영향을 함께 고려하여 선택할 필요 가 있다.

\subsection{NC-LDH|1M NaOH $\mid \mathrm{Fe}_{\mathrm{x}} \mathrm{O}_{\mathrm{y}}$ 를 이용한 $1.1 \mathrm{~V}$ 급 ARB}

Choi et al. 은 $\mathrm{NC}-\mathrm{LDH}$ 와 $\mathrm{Fe}_{3} \mathrm{O}_{4} / \mathrm{Fe}(\mathrm{OH})_{2}$ 복합체 를 각각 양극, 음극으로 하여 $\mathrm{ARB}$ 완전 전지를 보고했 다. ${ }^{39)} \mathrm{NC}-\mathrm{LDH}$ 는 $0.450 \mathrm{~V}$ (vs. SHE)에서 작동전압을 갖고, $\mathrm{Fe}_{3} \mathrm{O}_{4}$ 는 수소발생전압보다 $0.164 \mathrm{~V}$ 높은 -0.662 $\mathrm{V}$ (vs. SHE)에서 작동전압을 갖기 때문에 약 $1.1 \mathrm{~V}$ 의 작동전압을 갖는 $\mathrm{ARB}$ 를 구성할 수 있었다 (그림 7). 정 전류 주사법을 통해 확인한 결과, 양/음극 모두 안정적 인 반쪽 전지 반응을 할 수 있기 때문에 완전 전지 구 성에서도 안정적인 $\mathrm{ARB}$ 작동을 할 수 있었다. 1 분만에 $172 \mathrm{mAh} / \mathrm{g}$ 의 용량을 충전할 수 있어 급속 충전이 가능 한 $\mathrm{ARB}$ 시스템을 제시할 수 있었으며, 1 만회 충 · 방전 이후에도 초기 용량의 $70 \%$ 를 유지한다는 점은 주목할만 한 부분이라고 할 수 있다.

Choi et al. 은 X선 회절 및 흡수 미세구조 분석을 활 용하여 $\mathrm{LDH}$ 소재가 충 - 방전 과정에서 생기는 새로운 현상을 보고했다. 기존의 $\mathrm{LDH}$ 충전 메커니즘은 아래 식 (3)과 같이 수소 이온이 탈리되는 방식으로 일어난다고 이해되고 있었다.

$$
\mathrm{Ni}^{\mathrm{II}}(\mathrm{OH})_{2}-\mathrm{H} \rightarrow \mathrm{Ni}^{\mathrm{iII}} \mathrm{OOH}+\mathrm{e}^{-}
$$

그러나 실시간 $\mathrm{X}$ 선 회절 분석을 통해 확인해본 결과, 충전과정에서 (003)회절 피크의 강도가 약해지고 $10 \AA$ 과 $5 \AA$ 에 해당하는 새로운 회절 피크가 생기는 것을 발 견했다. 새로운 회절 피크가 건조 - 탈수 과정 이후에 사 라진다는 점을 통해 새롭게 생겨난 회절 피크는 충전 과 정에서 생긴 결정수에 의해 생겨난 것으로 이해할 수 있 었고, c축 방향으로의 새로운 정렬화(Ordering)에 기인 한다고 판단할 수 있었다 (그림 8).

실시간 X선 분석의 결과를 토대로 Choi et al.은 전해 질의 수산기 $\left(\mathrm{OH}^{-}\right)$이 층간으로 삽입(Intercalation)되어 $\mathrm{LDH}$ 격자 안에서 프로톤과 반응하고 그 결과 물 분자가 격자 내에서 결정화되며 결정수(Crystal water)를 생성 하고, 이 결정수들이 초격자(Superlattice)형태로 재배열 하면서 충전과정에서 생기는 격자 변형을 효율적으로 완 화시킬 수 있다는 점을 $\mathrm{LDH}$ 소재의 충전 메커니즘으로 제시했다 (그림 8B), 식 (4))

$$
\mathrm{Ni}^{\mathrm{II}}(\mathrm{OH})_{2}+\mathrm{OH}^{-}(\text {전해질 }) \rightarrow \mathrm{Ni}^{\mathrm{II}} \mathrm{OOH} \cdot\left(\mathrm{H}_{2} \mathrm{O}\right)
$$

이와 같은 메커니즘은 지난 30 여년간 잘못 이해된 $\mathrm{LDH}$ 소재의 충 - 방전 메커니즘을 명확한 결정학적인 근거로 재정립할 수 있었다는 점에서 중요한 발견이라 고 할 수 있다. 


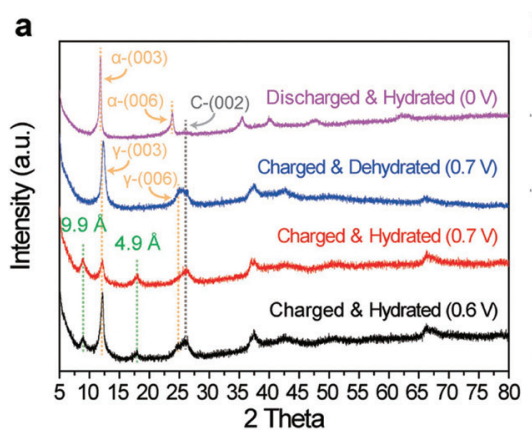

b

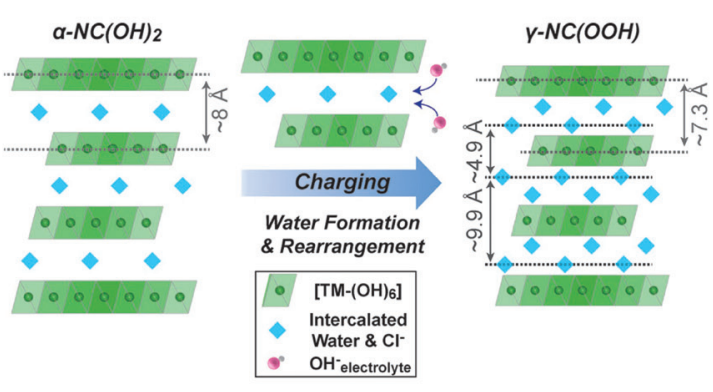

Fig. 8. (A) Ex situ XRD analysis of NC-LDH at different charge - discharge states. (B) Graphical illustration of the phase transition during electrochemical oxidation from NC-LDH (hydroxide) to NC-oxyhydroxide. Adapted from Choi et al. Adv Energy Mater 2018;18:1703572, with permission of Wiley Press [39]
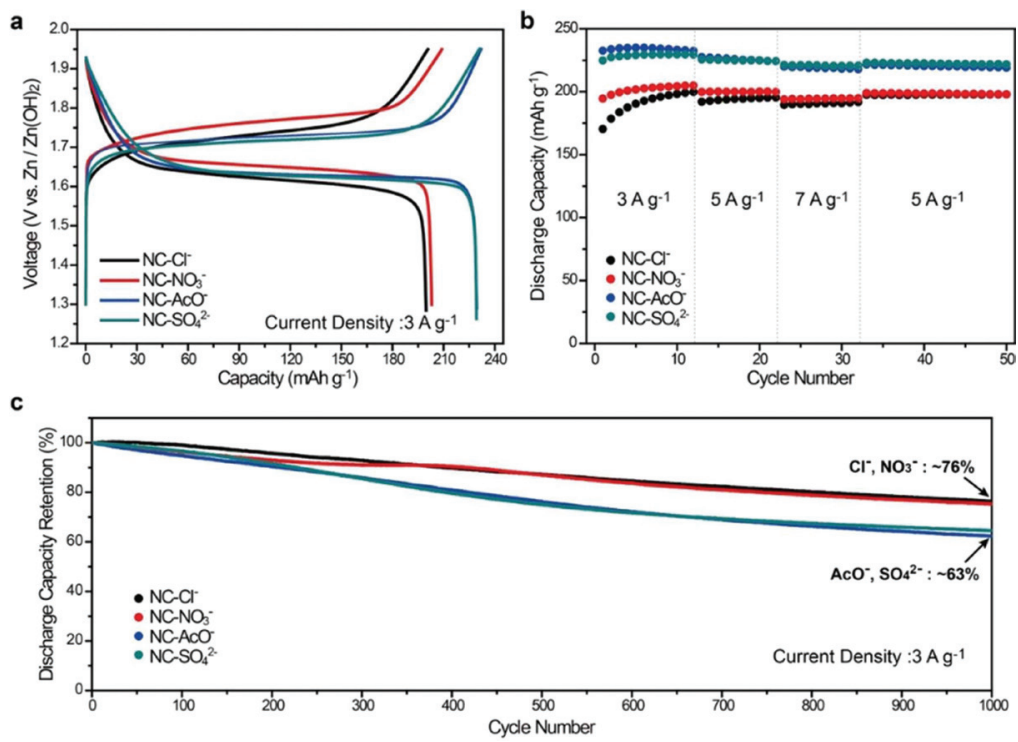

Fig. 9. Comparative galvanostatic charge/discharge curves of NC-LDH compounds with different anions measured at a current density of 3 A/g. Adapted from Lee et al. ChemSusChem 2020;13:6546-51, with permission of Wiley Press [40]

\subsection{NC-LDH|1M NaOH|Zn를 이용한 $1.7 \mathrm{~V}$ 급 ARB}

상기 3.1절에서 언급한 바와 같이 $\mathrm{LDH}$ 는 층간에 존 재하는 층간 삽입물을 이용해 c축 방향으로의 면간 거 리를 쉽게 제어할 수 있다. 이와 같은 면간 거리 제어 는 라우릴 황산 이온(Dodecyl sulfate; $\left.\left(\mathrm{C}_{12} \mathrm{H}_{25} \mathrm{SO}_{4}\right)^{-1}\right)$ 을 이용해 $\mathrm{LDH}$ 를 만들고, 다른 음이온들로 치환(Anion exchange)함으로써 얻을 수 있다. Kim et al. 은 이와 같은 방법을 통해 다른 종류의 음이온을 갖는 $\mathrm{Ni}-\mathrm{LDH}$ 들을 $\mathrm{ARB}$ 양극 소재로 평가했다. ${ }^{34)}$ 그러나, 집전체를
니켈 폼을 사용함으로써 $\mathrm{Ni}-\mathrm{LDH}$ 들의 용량에 미치는 면간 거리의 영향이 올바르게 파악되지 못했다.

Lee et al. 은 음이온 치환법이 아닌 서로 다른 음이온 (질산 이온 $\left(\mathrm{NO}_{3}{ }^{-}\right)$, 황산 이온 $\left(\mathrm{SO}_{4}\right)^{2-}$, 아세테이트 이온 $\left(\mathrm{CH}_{3} \mathrm{COO}^{-} ; \mathrm{AcO}\right)$, 염화 이온 $\left.\left(\mathrm{Cl}^{-}\right)\right)$을 활용해 다른 종류 의 음이온을 갖는 $\mathrm{NC}-\mathrm{LDH}$ 를 합성했고 이들을 $\mathrm{ARB}$ 양 극소재로 활용했다 (그림 9). ${ }^{40)}$ 음극은 아연 금속 $(\mathrm{Zn})$ 의 $\mathrm{Zn} / \mathrm{Zn}(\mathrm{OH})_{2}$ 레독스 커플을 이용해 약 $1.7 \mathrm{~V}$ 급의 작동 전압을 갖는 $\mathrm{ARB}$ 를 보고할 수 있었다. $\mathrm{Cl}$ 과 $\mathrm{NO}_{3}$ 를 음 이온으로 갖는 $\mathrm{NC}-\mathrm{LDH}$ 에 비해 $\mathrm{AcO}$ 와 $\mathrm{SO}_{4}$ 를 음이온 

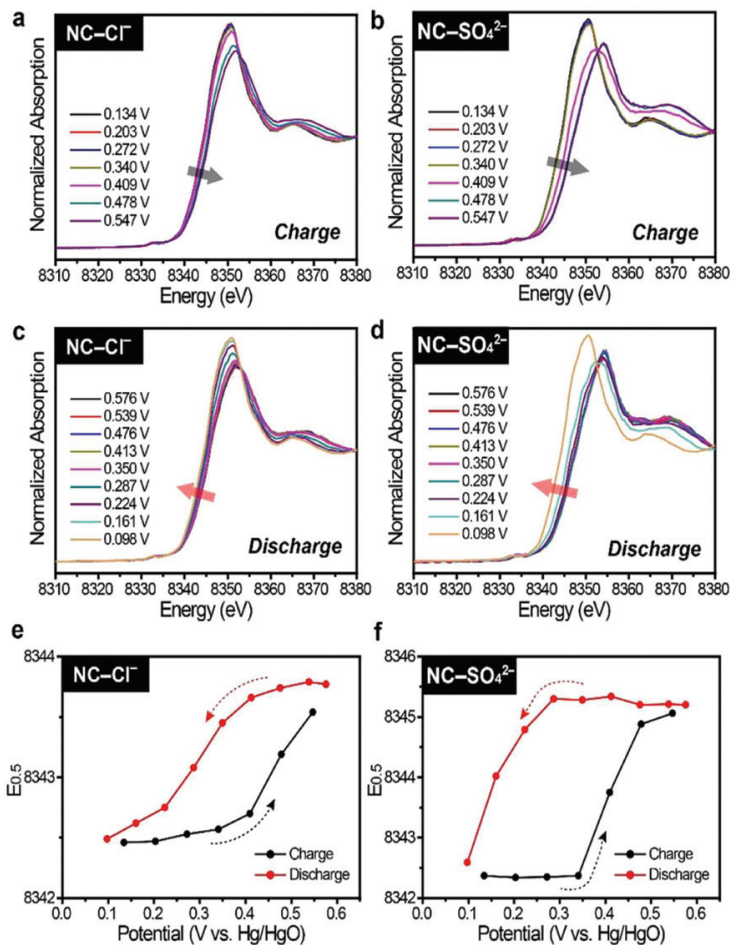

Fig. 10. In-situ $\mathrm{X}$-ray absorption fine structure analysis for $\mathrm{NC}-\mathrm{LDH}$ compounds with different anions. Adapted from Lee et al. ChemSusChem 2020;13:6546-51, with permission of Wiley Press [40]

으로 갖는 $\mathrm{NC}-\mathrm{LDH}$ 는 약 $25 \mathrm{mAh} / \mathrm{g}$ 가량 높은 용량을 보였다. 그러나, $3 \mathrm{~A} / \mathrm{g}$ 의 전류 밀도로 1 천회 충 - 방전 이후 $\mathrm{Cl}$ 과 $\mathrm{NO}_{3}$ 를 음이온으로 갖는 $\mathrm{NC}-\mathrm{LDH}$ 는 약 $76 \%$ 의 초기 용량을 유지했고, $\mathrm{AcO}$ 와 $\mathrm{SO}_{4}$ 를 음이온으로 갖 는 $\mathrm{NC}-\mathrm{LDH}$ 는 약 $63 \%$ 의 초기 용량을 유지하는 것을 통해 용량-수명 특성 간에 Trade-off 관계가 있음을 보고했다.

이와 같은 Trade-off는 음이온의 유효 전하 (Effective charge), 음이온의 유효 크기(Effective size) 등과는 무관하며 오로지 결정화도(Crystallinity) 에 의해 결정된다는 점을 실시간 $\mathrm{X}$ 선 흡수 분석을 통 해 밝혔다 (그림 10). 결정성이 좋은 $\mathrm{NC}-\mathrm{LDH}$ (음이온: $\mathrm{Cl}^{-}$)의 경우 $\mathrm{Ni}$ 의 레독스 반응이 일어날 때 생기는 격 자 변형을 쉽게 수용하지 못하기 때문에 $\mathrm{Ni}$ 산화수 변화 폭이 상대적으로 적어 가용 용량이 낮은 반면, 결정성이
낮은 $\mathrm{NC}-\mathrm{LDH}\left(\right.$ 음이온: $\mathrm{SO}_{4}{ }^{2-}$ )는 $\mathrm{Ni}$ 산화수 변화폭이 상대적으로 커서 가용 용량이 큰 것을 알 수 있다. 결정 화도에 따라 충 - 방전 과정에서 생기는 격자 변형을 수 용하는 방식이 달라 수명 특성에 영향을 미치는 것을 확 인할 수 있었다. $\mathrm{NC}-\mathrm{LDH}$ (음이온: $\mathrm{Cl}^{-}$)의 경우, 충 - 방 전 과정에서 점진적으로 $\mathrm{Ni}$ 의 산화수가 변하지만, $\mathrm{NC}-$ $\mathrm{LDH}$ (음이온: $\mathrm{SO}_{4}{ }^{2-}$ )는 급격하게 $\mathrm{Ni}$ 의 산화수가 변하는 것을 알 수 있다. 이를 통해 $\mathrm{Cl}$ 과 $\mathrm{NO}_{3}$ 를 음이온으로 갖 는 $\mathrm{NC}-\mathrm{LDH}$ 들이 점진적으로 격자 변형을 수용할 수 있 기 때문에 더 좋은 수명 특성을 갖는 것으로 이해할 수 있다.

\section{4. 결론}

본 총설에서는 $\mathrm{LIB}$ 소재들을 $\mathrm{ARB}$ 에 적용했을 때, 수 계 전해질과의 부반응(Side reaction)에서 생기는 열 화 메커니즘과 $\mathrm{LDH}$ 를 활용한 차세대 $\mathrm{ARB}$ 시스템의 연 구동향에 관해서 리뷰했다. LIB 소재들은 수계 전해질 에서 단순히 물과의 부반응을 통해서 열화가 일어나는 것이 아닌, 용존 산소 · 작동 온도 · 작동전압(=충전 정 도) 등 복합적인 요인에 의해 열화가 일어난다. 따라서, 습지, 바닷가, 냇가 등에서 발견되는 대부분의 미네랄 구조가 수화물임을 생각해보면 수화물 구조를 활용해 $\mathrm{ARB}$ 전극 소재를 개발하는 것은 합리적인 선택이라고 할 수 있다. 이러한 관점에서 결정수와 음이온을 전이금 속 층 사이에 갖고 있는 $\mathrm{LDH}$ 는 $\mathrm{ARB}$ 전극으로서 많은 장점을 갖고 있는 소재라고 할 수 있다. 특히, $\mathrm{Ni}$ 의 넓은 산화수 범위 $\left(\mathrm{Ni}^{2+} \leftrightarrow \mathrm{Ni}^{4+}\right)$ 를 활용하여 많은 가용 용량을 확보하고 $\mathrm{Ni}^{3+}$ 의 얀-텔러 뒤틀림을 완화시킬 수 있는 다른 전이금속을 치환하면 고용량 - 장수명 특성을 확보 한 $\mathrm{LDH}$ 소재를 디자인할 수 있다. 이때, 치환된 전이금 속에 의해 $\mathrm{Ni}$ 의 레독스 커플 에너지가 변하기 때문에 물 의 전기화학적 가용 범위를 고려한 적절한 최적화가 필 요할 것이다. 전이금속의 영향뿐만 아니라, 층 간에 위 치한 음이온 또한 $\mathrm{LDH}$ 의 전기화학적 성능에 영향을 미 친다. 특히, 음이온의 가수, 크기 등이 전기화학적 성능 에 직접적인 영향을 미치기보다는 음이온의 선택에 따 
른 결정수와 전이금속 층의 결합력에 의한 결정화도 정 도가 전반적인 전기화학적 성능에 크게 영향을 미치는 것으로 생각된다. 끝으로, $\mathrm{NC}-\mathrm{LDH}$ 양극과 철 산화물 $\left(\mathrm{Fe}_{3} \mathrm{O}_{4}\right) /$ 아연 금속 $(\mathrm{Zn})$ 을 음극으로 이용해 $1.1 \mathrm{~V}$ 급/1.7 $\mathrm{V}$ 급 $\mathrm{ARB}$ 시스템을 제시하며 $\mathrm{LIB}$ 수준에 근접한 고성능 $\mathrm{ARB}$ 시스템의 현 주소도 살펴보았다. 본 총설에서 언 급한 $\mathrm{ARB}$ 에 관한 동향은 앞으로 다양한 $\mathrm{ARB}$ 용 수화물 소재 및 $\mathrm{ARB}$ 시스템 연구 등에 활용할 수 있을 것으로 기대된다.

\section{REFERENCES}

1. W. Li, J.R. Dahn, D.S. Wainwright, Rechargeable Lithium Batteries with Aqueous Electrolytes, Science, 264 [5162] 1115-1118 (1994).

2. B. Dunn, H. Kamath, J.-M. Tarascon, Electrical Energy Storage for the Grid: a Battery of Choices, Science, 334 [6058] 928-935 (2011).

3. R.A. Huggins, Energy Storage: Fundamentals, Materials and Applications, Springer, 2015.

4. D. Han, K.-W. Nam, In situ Synchrotron X-ray Techniques for Structural Investigation of Electrode Materials for Li-ion Battery, Ceramist, 22 [4] 402-416 (2019).

5. J. Jo, J. Kim, Recent Research Trend of Zinc-ion Secondary Battery Materials for Next Generation Batterie, Ceramist, 21 [4] 312-330 (2018).

6. J.-Y. Luo, W.-J. Cui, P. He, Y.-Y. Xia, Raising the cycling stability of aqueous lithium-ion batteries by eliminating oxygen in the electrolyte, Nat. Chem., 2 [9] 760-765 (2010).

7. J. Köhler, H. Makihara, H. Uegaito, H. Inoue, M. Toki, $\mathrm{LiV}_{3} \mathrm{O}_{8}$ : characterization as anode material for an aqueous rechargeable Li-ion battery system, Electrochim. Acta, 46 [1] 59-65 (2000).

8. H. Wang, K. Huang, Y. Zeng, S. Yang, L. Chen, Electrochemical properties of $\mathrm{TiP}_{2} \mathrm{O}_{7}$ and $\mathrm{LiTi}_{2}\left(\mathrm{PO}_{4}\right)_{3}$ as anode material for lithium ion battery with aqueous solution electrolyte, Electrochim. Acta, 52 [9] 32803285 (2007).

9. J. Choi, E. Alvarez, T. Arunkumar, A. Manthiram,
Proton insertion into oxide cathodes during chemical delithiation, Electrochem. Solid State Lett., 9 [5] A241-A244 (2006).

10. A. Manthiram, J. Choi, Chemical and structural instabilities of lithium ion battery cathodes, J. Power Sources, 159 [1] 249-253 (2006).

11. Y.-g. Wang, Y.-y. Xia, Hybrid Aqueous Energy Storage Cells Using Activated Carbon and LithiumIntercalated Compounds: I. The System, J. Electrochem. Soc., 153 [2] A450 (2006).

12. Y.-g. Wang, J.-y. Luo, C.-x. Wang, Y.-y. Xia, Hybrid Aqueous Energy Storage Cells Using Activated Carbon and Lithium-Ion Intercalated Compounds: II. Comparison of, and Positive Electrodes, J. Electrochem. Soc., 153 [8] A1425 (2006).

13. J.-H. Shim, K.-S. Lee, A. Missyul, J. Lee, B. Linn, E.C. Lee, S. Lee, Characterization of Spinel $\mathrm{Li}_{\mathrm{x}} \mathrm{Co}_{2} \mathrm{O}_{4}-$ Coated $\mathrm{LiCoO}_{2}$ Prepared with Post-Thermal Treatment as a Cathode Material for Lithium Ion Batteries, Chem. Mater., 27 [9] 3273-3279 (2015).

14. P. He, J.-L. Liu, W.-J. Cui, J.-Y. Luo, Y.-Y. Xia, Investigation on Capacity Fading of $\mathrm{LiFePO}_{4}$ in Aqueous Electrolyte, Electrochim. Acta, 56 [5] 23512357 (2011).

15. P. Byeon, H.B. Bae, H.S. Chung, S.G. Lee, J.G. Kim, H.J. Lee, J.W. Choi, S.Y. Chung, Atomic-scale observation of $\mathrm{LiFePO}_{4}$ and $\mathrm{LiCoO}_{2}$ dissolution behavior in aqueous solutions, Adv. Funct. Mater., 28 [45] 1804564 (2018).

16. H.J. Lee, J.H. Lee, I.H. Son, S. Han, P. Byeon, M.-S. Park, S.-Y. Chung, J.W. Choi, Off-Stoichiometry Induced Few-Nanometer Surface Layer for HighPerformance Layered Cathode in Nonaqueous and Aqueous Electrolytes, ACS Appl. Energy Mater., 1 [10] 5726-5734 (2018).

17. H.J. Lee, J. Shin, J.W. Choi, Intercalated water and organic molecules for electrode materials of rechargeable batteries, Adv. Mater., 30 [42] 1705851 (2018).

18. D.G. Evans, R.C.T. Slade, Structural Aspects of Layered Double Hydroxides, in: X. Duan, D.G. Evans (Eds.) Layered Double Hydroxides, Springer Science \& Business Media, 2006, pp. 1-87.

19. Z.P. Liu, R.Z. Ma, M. Osada, K. Takada, T. Sasaki, Selective and Controlled Synthesis of $\alpha$ - and $\beta$-cobalt Hydroxides in Highly Developed Hexagonal Platelets, 
J. Am. Chem. Soc., 127 [40] 13869-13874 (2005).

20. R. Jayashree, P.V. Kamath, Suppression of the $\alpha \rightarrow$ $\beta$-Nickel Hydroxide Transformation in Concentrated Alkali: Role of Dissolved Cations, J. Appl. Electrochem., 31 [12] 1315-1320 (2001).

21. H.L. Wang, H.S. Casalongue, Y.Y. Liang, H.J. Dai, $\mathrm{Ni}(\mathrm{OH})_{2}$ Nanoplates Grown on Graphene as Advanced Electrochemical Pseudocapacitor Materials, J. Am. Chem. Soc., 132 [21] 7472-7477 (2010).

22. H. Bode, K. Dehmelt, J. Witte, Zur Kenntnis Der Nickelhydroxidelektrode-I. Über Das Nickel(II)Hydroxidhydrat, Electrochimica Acta, 11 [8] 10791087 (1966).

23. M. Catti, G. Ferraris, S. Hull, A. Pavese, Static compression and $\mathrm{H}$ disorder in brucite, $\mathrm{Mg}(\mathrm{OH})_{2}$, to $11 \mathrm{GPa}$ a powder neutron diffraction study, Phy. Chem. Miner., 22 [3] 200-206 (1995).

24. T. Nagai, T. Hattori, T. Yamanaka, Compression mechanism of brucite: An investigation by structural refinement under pressure, Amer. Mineral., 85 [5-6] 760-764 (2000).

25. H. Lutz, W. Eckers, H. Haeuseler, OH stretching frequencies of solid hydroxides and of free $\mathrm{OH}^{-}$ions, J. Mol. Struc., 80 [221-224 (1982).

26. H.M. Du, L.F. Jiao, K.Z. Cao, Y.J. Wang, H.T. Yuan, Polyol-Mediated Synthesis of Mesoporous alpha$\mathrm{Ni}(\mathrm{OH})_{2}$ with Enhanced Supercapacitance, ACS Appl. Mater. Inter., 5 [14] 6643-6648 (2013).

27. S. Huang, G.N. Zhu, C. Zhang, W.W. Tjiu, Y.Y. Xia, T.X. Liu, Immobilization of Co-Al Layered Double Hydroxides on Graphene Oxide Nanosheets: Growth Mechanism and Supercapacitor Studies, ACS Appl. Mater. Inter., 4 [4] 2242-2249 (2012).

28. H. Chen, L.F. Hu, M. Chen, Y. Yan, L.M. Wu, NickelCobalt Layered Double Hydroxide Nanosheets for High-performance Supercapacitor Electrode Materials, Adv. Funct. Mater., 24 [7] 934-942 (2014).

29. J. Yan, Z.J. Fan, W. Sun, G.Q. Ning, T. Wei, Q. Zhang, R.F. Zhang, L.J. Zhi, F. Wei, Advanced Asymmetric Supercapacitors Based on $\mathrm{Ni}(\mathrm{OH})_{2} /$ Graphene and Porous Graphene Electrodes with High Energy Density, Adv. Funct. Mater., 22 [12] 26322641 (2012).

30. G.W. Yang, C.L. Xu, H.L. Li, Electrodeposited Nickel Hydroxide on Nickel Foam with Ultrahigh
Capacitance, Chem. Commun., [48] 6537-6539 (2008).

31. Z. Gao, J. Wang, Z.S. Li, W.L. Yang, B. Wang, M.J. Hou, Y. He, Q. Liu, T. Mann, P.P. Yang, M.L. Zhang, L.H. Liu, Graphene Nanosheet $/ \mathrm{Ni}^{2+} / \mathrm{Al}^{3+}$ Layered Double-Hydroxide Composite as a Novel Electrode for a Supercapacitor, Chem. Mater., 23 [15] 35093516 (2011).

32. Y.M. Li, W.Y. Li, S.L. Chou, J. Chen, Synthesis, characterization and electrochemical properties of aluminum-substituted alpha- $\mathrm{Ni}(\mathrm{OH})_{2}$ hollow spheres, J. Alloy. Comp. , 456 [1-2] 339-343 (2008).

33. Y.H. Gu, Z.Y. Lu, Z. Chang, J.F. Liu, X.D. Lei, Y.P. Li, X.M. Sun, NiTi layered double hydroxide thin films for advanced pseudocapacitor electrodes, J. Mater. Chem. A, 1 [36] 10655-10661 (2013).

34. J.W. Lee, J.M. Ko, J.D. Kim, Hierarchical Microspheres Based on alpha-Ni(OH $)_{2}$ Nanosheets Intercalated with Different Anions: Synthesis, Anion Exchange, and Effect of Intercalated Anions on Electrochemical Capacitance, J. Phys. Chem. C, 115 [39] 19445-19454 (2011).

35. Y.Q. Zhu, C.B. Cao, S. Tao, W.S. Chu, Z.Y. Wu, Y.D. Li, Ultrathin Nickel Hydroxide and Oxide Nanosheets: Synthesis, Characterizations and Excellent Supercapacitor Performances, Sci. Rep., 4 [5787 (2014).

36. W. Xing, S.Z. Qiao, X.Z. Wu, X.L. Gao, J. Zhou, S.P. Zhuo, S.B. Hartono, D. Hulicova-Jurcakova, Exaggerated Capacitance using Electrochemically Active Nickel Foam as Current Collector in Electrochemical Measurement, J. Power Sources, 196 [8] 4123-4127 (2011).

37. J.H. Lee, H.J. Lee, S.Y. Lim, K.H. Chae, S.H. Park, K.Y. Chung, E. Deniz, J.W. Choi, Stabilized Octahedral Frameworks in Layered Double Hydroxides by Solid-Solution Mixing of Transition Metals, Adv. Funct. Mater., 27 [7] 1605225 (2017).

38. J.E. Huheey, E. Keiter, R. Keiter, Inorganic Chemistry: Principles of Structure and Reactivity (4th Edition), Harper Collins College Publishers, New York, 1993.

39. J.H. Lee, H.J. Lee, S.H. Choi, J. Shin, S.Y. Chung, J.W. Choi, Superlattice Formation of Crystal Water in Layered Double Hydroxides for Long-Term and Fast Operation of Aqueous Rechargeable Batteries, Adv. 


\section{특 집}

Energy Mater., 8 [18] 1703572 (2018).

40. H.J. Lee, J.H. Lee, J.W. Choi, Effect of Binding
Affinity of Crystal Water on the Electrochemical Performance of Layered Double Hydroxides, ChemSusChem, 13 [24] 6546-6551 (2020).

\section{○이현 정}

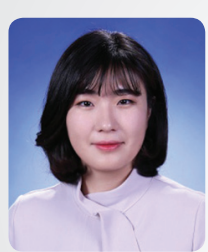

( 2008.03-2014.02 KAIST 생명화학공학과 학사

ㅇ 2014.03-2016.02 KAIST EEWS대학원 석사

( 2016.03-2018.02 KAIST EEWS대학원 박사

○ 2018.03-2018.12 서울대학교 화학생물공학부 박사 후 연구원

- 2019.01-현 재 University of Oxford 재료과 박사 후 연구원

\section{○๑ 이 지 훈}

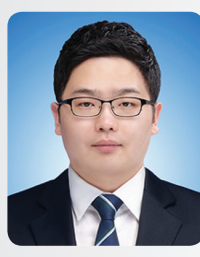

- 2006.03-2011.08 서울시립대학교 신소재공학과 학사

○ 2011.09-2013.02 KAIST EEWS대학원 석사

- 2013.03-2017.02 KAIST EEWS대학원 박사

○ 2017.02-2017.07 KAIST 응용과학연구소 박사 후 연구원

- 2017.08-2020.08 Columbia University 화학공학과 박사 후 연구원

- 2020.09-현 재 경북대학교 신소재공학부 조교수 